Jurnal MAKSIPRENEUR, Vol. VI, No. 1, Desember 2016, hal. 1 - 13

\title{
SIKAP KONSUMEN TERHADAP PELAYANAN PUSAT KULINER BELUT GODEAN SLEMAN YOGYAKARTA
}

Edy Rismiyanto (edyrismiyanto@yahoo.com)

Totok Danangdjojo (totokdanangdjojo@yahoo.co.id)

Fakultas Ekonomi Universitas Proklamasi 45

\begin{abstract}
ABTRACT. Tourism industry growing rapidly nowadays is in culinary field which relates to food and beverage supply. The tourist trend recently is visiting a destination to look for or hunt for the local special food and do not hesitate to pay in high price to enjoy the cuisine. Special culinary tour of Yogyakarta becomes one of the tourism attractions of Special Region of Yogyakarta that be able to get great benefits toward community economy. Eel culinary business is potential to grow the local society economy. The aim of the research is to find out consumer attitude toward service center of Eel culinary at Godean Sleman Yogyakarta. Data collection technique used is questionnaire and sampling method used convenient sampling method.As for the research steps consisted of: 1) preparation step of the research instrument included literature review, research design setting and earlier observation, 2) step of data collection in the field is conducted by observation, questionnaire, interview, and secondary data collection, 3) step of data tabulation and analysis, consisted of: a) data component tabulation, including data reduction and data presentation, b) data verification including data validity, c) data analysis, using attitude index analysis method, 4) step of report writing as the final step of the research, where all results analyzed was presented in a structured written product. From the analysis using attitude index was obtained a value of 8,71 means the consumers have neutral attitude toward the service center of Eel culinary at Godean Sleman Yogyakarta. As for the attributes the best responded were access, credibility and tangible (parking are), and the worst responded attribute was (religious service).
\end{abstract}

Keywords: consumer's attitude, culinary tour of Eel Godean, effect toward the society economy

\section{PENDAHULUAN}

Pembangunan pariwisata dapat memberikan peluang bergeraknya berbagai kegiatan ekonomi masyarakat. Oleh karena itu, sektor pariwisata merupakan salah satu sektor yang mampu mengintegrasikan kemajuan perekonomian pada berbagai dimensi pada skala nasional, rcgional, dan global. Salah satu potensi wisata yang terus dikembangkan dalam rangka meningkatkan perekonomian masyarakat adalah wisata kuliner yang merupakan bagian dari sektor pariwisata global. 
Industri pariwisata yang sekarang sedang mengalami perkembangan pesat adalah bidang kuliner yaitu wisata yang berkaitan dengan penyediaan makanan dan minuman. Trend wisatawan sekarang adalah datang ke suatu daerah wisata untuk mencari atau berburu makanan khas daerah tersebut dan tidak segan-segan membayar mahal untuk menikmati suatu hidangan. Perubahan gaya hidup masyarakat juga telah terjadi, mereka makan tidak hanya untuk mengenyangkan perut saja, tetapi juga mencari suasana dan pelayanan sebagai bagian dari sajian makanan yang dipesan. Banyak restoran dan tempat makan baru didirikan dengan kualifikasi dan ciri khas masing-masing. Beragam sajian ditawarkan mulai dari makanan khas daerah yang sifatnya tradisional sampai makananmakanan cepat saji yang bersifat modern. Selain menikmati kuliner di restoran dan rumah makan, para wisatawan juga tertarik untuk mcmbeli makanan khas sebagai oleh-oleh. Hal ini tentunya memberikan peluang bagi perkembangan belut di Godean, Sleman, Provinsi Daerah Istimewa Yogyakarta merupakan salah satu wilayah tujuan wisata di Indonesia yang menawarkan berbagai macam obyek wisata baik obyek wisata alam, wisata pantai, maupun wisata budayanya. Mengingat pariwisata mendatangkan devisa yang banyak maka pemerintah D.I.Yogyakarta menetapkan sektor pariwisata sebagai salah satu sektor unggulan. Kontribusi yang dapat diandalkan dalam pembangunan ekonomi DIY pada sektor pariwisata, diantaranya industri pariwisata dan jasa-jasa, dapat menciptakan lapangan pekerjaan baru bagi masyarakat yang secara langsung dapat meningkatkan pendapatan asli daerah. Tingginya jumlah wisatawan yang datang ke DIY merupakan peluang yang positif bagi pertumbuhan wisata kuliner di DIY, khususnya kuliner oleholeh khas Yogyakarta. Hal ini tentu mendatangkan dampak yang positif bagi perekonomian masyarakat setempat.

Wisata kuliner Belut Godean Yogyakarta menjadi salah satu daya wisata DIY yang mampu mendatangkan manfaat yang besar terhadap perekenomian masyarakat. Sudah bukan rahasia umum jika Yogyakarta memiliki makanan dan oleh-oleh khas, seperti bakpia, geplak, yangko, gudeg, jadah tempe, kipo, belut dan lain-lain. Hal inilah yang mendorong wisatawan tertarik untuk mencicipi kuliner khas Yogyakarta.

Bisnis oleh-oleh khas Yogyakarta belut ternyata dapat memberikan keuntungan ekonomis bagi masyarakat. Hal ini secara tidak langsung menunjukkan dampak positif pariwisata terhadap pertumbuhan bisnis makanan dan oleh-oleh khas Yogyakarta. Kondisi tersebut tentu memberikan efek positif terhadap perekonomian masyarakat karena umumnya bisnis kuliner belut masih bersifat padat karya. Sayangnya penelitian tentang sikat masyarakat wisata kuliner oleh-oleh khas Yogyakarta terhadap pelayanan Pusat Kuliner Belut Godean, sehingga peneliti tertarik untuk mengkajinya secara lebih mendalam.

\section{TUJUAN DAN MANFAAT PENELITIAN}

Tujuan penelitian ini adalah untuk mengetahui sikap konsumen terhadap pelayanan pusat kuliner belut Godean Sleman Yogyakarta. Pelayanan diukur melalui atribut pelayanan yang meliputi reliability, responsivess, competence, access, courtecy, comunication, credibility, security, understanding dan tangibles. Adapun hasil temuan dalam penelitian ini diharapkan akan bermanfaat bagi:

a. Sponsor atau pemerintah sebagai salah satu pertimbangan pemerintah dalam mengembangkan wisata kuliner (belut) yang memberi dampak positif bagi 
pembangunan dan perekonomian masyarakat setempat, khususnya kecamatan Godean Kabupaten Sleman.

b. Bagi pengusaha kecil/pengusaha kuliner agar ada tindak lanjutnya dari pemerintah maupun lembaga swadaya masyarakat dan swasta yang bergerak di bidang pengembangan wisata kuliner.

\section{TINJAUAN PUSTAKA}

a. Konsep Pariwisata

Dalam undang-undang Nomor 10 tahun 2009 tentang kepariwisataan menyebutkan bahwa wisata adalah kegiatan perjalanan atau sebagian dari kegiatan tersebut yang dilakukan secara sukarela serta bersifat sementara untuk menikmati obyek dan daya tarik wisata. Jadi pengertian wisata mengandung unsunesementara dan perjalanan itu seluruhnya atau sebagian bertujuan untuk menikmati obyek atau daya tarik wisata. Unsur yang terpenting dalam kegiatan wisata adalah tidak bertujuan mencari nafkah, tetapi apabila di sela-sela kegiatan mencari nafkah itu juga secara khusus dilakukan kegiatan wisata, bagian dari kegiatan tersebut dapat dianggap sebagai kegiatan wisata.

Menurut arti katanya, pariwisata berasal dari bahasa Sansekerta yang terdiri dari dua kata yaitu kata Pari dan kata Wisata. Kata Pari berarti penuh, seluruh, atau semua dan kata wisata berarti perjalanan. Menurut Yoeti (2003), syarat suatu perjalanan disebut sebagai perjalanan pariwisata apabila:

1) Perjalanan dilakukan dari suatu tempat ke tempat yang lain, di luar tempat kediaman orang tersebut biasa tinggal;

2) Tujuan perjalanan semata-mata untuk bersenang-senang, dan tidak mencari nafkah di tempat atau negara yang dikunjunginya; 3) Semata-mata sebagai konsumen di tempat yang dikunjungi.

\section{b. Konsep Wisata Kuliner}

Wisata kuliner dapat didefinisikan sebagai wisata yang menyediakan berbagai fasilitas pelayanan dan aktivitas kuliner yang terpadu untuk memenuhi kebutuhan wisatawan yang dibangun untuk rekreasi, relaksasi, pendidikan dan kesehatan (Suryadana, 2009). Daya tarik wisata kuliner menurut Suryadana (2009) meliputi:

1) Keragaman aktivitas kuliner,

2) Makanan khas,

3) Lokasi yang nyaman dan bersih,

4) Desain ruangan (yenue) yang unik dan menarik,

5) Pelayanan yang baik,

6) Pasar yang kompetitif,

7) Harga dan proporsi nilai,

8) Peluang bersosialisasi,

9) Interaksi budaya dengan kuliner,

10) Suasana kekeluargaan,

11) Lingkungan yang menarik,

12) Produk tradisional, nasional \& Internasional

Kuliner adalah suatu kegiatan hidup yang erat kaitannya dengan konsumsi makanan sehari-hari dan kuliner merupakan sebuah gaya hidup yang tidak dapat dipisahkan dari kehidupan sehari-hari, di mana kuliner dapat mengembangkan perekonomian daerah 
sesuai makanan khas daerah yang dapat menciptakan lapangan kerja dan mengentaskan kemiskinan melalui kegiatan wisata kuliner. Oleh karena itu, kuliner perlu dimasukkan ke dalam sektor pengembangan ekonomi kreatif (Jumal Kajian Lemhanas, 2012).

\section{c. Unsur Pariwisata}

Unsur pokok yang harus mendapat perhatian guna menunjang pariwisata di daerah tujuan wisata menurut Suwantoro (2004) meliputi:

1) Obyek dan daya tarik wisata,

2) Prasarana wisata,

3) Sarana wisata

d. Dampak Obyek Wisata terhadap Perekonomian Masyarakat

Menurut Dorodjatun dalam Yoeti (2008), tujuan pengembangan pariwisata bukan hanya sekedar peningkatan perolehan devisa bagi negara, pariwisata diharapkan sebagai katalisator pembangunan. Menurutnya ada delapan keuntungan yang bisa diperoleh dan pembangunan pariwisata yaitu: 1) peningkatan kesempatan berusaha, 2) peningkatan kesempatan kerja, 3) peningkatan penerimaan pajak, 4) peningkatan pendapatan nasional, 5) percepatan poses pemerataan pendapatan nasional, 6) peningkatan nilai tambah produk hasil kebudayaan, 7) memperluas pasar produk dalam negcri, 8) memberikan dampak multiplier effect dalam perekonomian sebagai akibat pengeluaran wisatawan, investor, maupun perdagangan dalam negeri.

Pengembangan pariwisata banyak mendatangkan manfaat ekonomi, tetapi jika tidak direncanakan dengan baik, akan menimbulkan dampak yang cukup banyak. Dampak ekonomi yang dimaksud sebagaimana dipaparkan oleh Wahyudi (2012) meliputi: 1) Pekerjaan yang diciptakan memerlukan sedikit keterampilan, 2) Peningkatan harga, 3) Nilai properti meningkat, 4) Jika pariwisata musiman di tempat tujuan, jadi juga akan injeksi pendapatan ke masyarakat, 5) Penyediaan layanan kesehatan dan layanan polisi bisa meningkat, 6) Keterjangkauan dan ketersediaan perumahan staf bisa rnenimbulkan masalah.

Disamping itu juga dampak pariwisata terhadap kondisi sosial ekonomi masyarakat lokal dapat dikatagorikan menjadi delapan kelompok besar (Cohen, 1984 dalam Wahyudi, 2012) yaitu: 1) Dampak terhadap penerimaan devisa, 2) Dampak terhadap pendapatan masyarakat, 3) Dampak terhadap kesempatan kerja, 4) Dampak terhadap harga-harga, 5) Dampak terhadap distribusi manfaat/ keuntungan, 6) Dampak terhadap kepemilikan dan kontrol, 7) Dampak terhadap pembangunan pada umumnya, dan 8) Dampak terhadap pendapatan pemerintah.

Mubyarto dalam Yoeti (2008) mengatakan bahwa pariwisata merupakan suatu sektor ekonomi yang yang terbukti mampu mengentaskan kemiskinan pada suatu daerah. Menurutnya, pembangunan industri pariwisata yang mampu mengentaskan kemiskinan adalah industri pariwisata yang mempunyai trickle down effect bagi masyarakat setempat.

Saat ini pariwisata menduduki peringkat kedua penghasil devisa negara setelah migas. Diproyeksikan pada waktu yang akan datang, pariwisata sebagai industri akan menggantikan posisi migas sebagai penghasil devisa negara terbesar. 
Bagian pendapatan yang dikeluarkan oleh wisatawan dalam melakukan transaksi barang dan jasa di daerah tujuan wisata berupa biaya akomodasi, transportasi, konsumsi, atraksi wisata, pembelian cenderamata akan mempengaruhi tingkat pertumbuhan ekonomi daerah.

Pariwisata sebagai manifestasi dari modemisasi yang dapat memberikan dampak positif langsung terhadap perekonomian masyarakat, yaitu baik penciptaan lapangan keija dan berusaha maupun peningkatan pendapatan rurnah tangga. Selain itu pengcmbangan kepariwisataan dapat juga memberikan dampak negatif dan dampak positif terhadap lingkungan sosial ekonomi. Dampak-dampak yang timbul tersebut dapat digambarkan secara sederhana dalam model diagram input-output berikut ini:

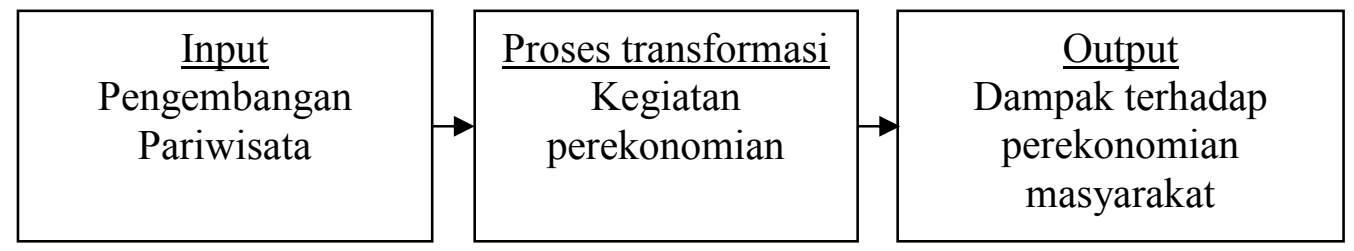

Gambar 1. Input-output kegiatan pariwisata terhadap perekonomian masyarakat

Yoeti (2008) menyatakan bahwa untuk menghindari terjadinya urbanisasi yaitu mengalimya pencari kerja ke kota-kota besar, pemerintah daerah perlu mengembangkan industri pariwisata di daerah sehingga mampu menyediakan lapangan pekeriaan dengan banyaknya proyek pariwisata di daerah. Namun, masalah yang sering dihadapi adalah rendahnya tingkat pendidikan dan keterampilan penduduk lokal sehingga tenaga profesional dan terampil terpaksa perlu didatangkan dari kota-kota besar. Hal tersebut menimbulkan kecemburuan sosial sehingga mengakibatkan gagalnya proyek kepariwisataan di daerah tersebut. Idealnya, pengembangan dan pembangunan pariwisata dapat memberikan keuntungan bagi investor, wisatawan, serta kesejahteraan bagi penduduk setempat.

\section{e. Pengertian Sikap}

Salah satu elemen yang sangat menonjol pada sikap adalah perasaan emosional baik yang positif maupun yang negatif terhadap sebuah barang atau jasa, Sikap dan kepercayaan merupakan faktor yang ikut mempengaruhi pandangan dan sikap konsumen terhadap pembelian sebuah barang ataupun jasa yang dibutuhkannya. Adapun definisi sikap menurut Fishbein dalam peter (2000) yang umumnya diterima, dapat diartikan kedalam 4 kelompok yaitu: 1) Sikap adalah suatu masalah yang baik atau kurang baik maupun kontra perasaan seseorang terhadap objek, 2) Memandang sikap sebagai hal yang mudah dipengaruhi untuk menjawab kepada suatu objek yang konsisten, 3) Sikap dipopelerkan oleh pengamatan psikologis timur yaitu suatu organisasi yang mempunyai motivasi, kesabaran, emosional, hal yang dapat diamati dan proses pengamatan dengan mengarap beberapa aspek dari pada dunia individu, 4) Sikap sudah dapat mempertimbangkan keputusan terhadap suatu objek, yang mana hal itu telah diperlihatkan, bahwa para konsumen meneliti suatu produk atau objek yang mempunyai banyak atribut-atribut dan membentuk kepercayaan terhadap tiap-tiap atribut tersebut.

Model sikap Fishbein adalah sikap seseorang secara keseluruhan terhadap objek, diperoleh dari kepercayaan serta evaluasi tentang berbagai sifat objek, dan dalam 
pengukurannya digunakan skala bipolar (skala yang mempunyai 2 kutub) formulasinya sebagai berikut:

$$
\mathrm{Ao}=\sum_{i=1}^{n} b_{i} \cdot e_{i}
$$

Untuk mengetahui sikap seseorang perlu adanya pemrosesan informasi tentang kepercayaan dan evaluasi yang diberikan terhadap suatu produk, Sikap konsumen secara keseluruhan (Ao) diperoleh dengan jalan mengalikan skor kepercayaan (bi) dengan evaluasi (ei), dalam penelitian ini untuk mencari nilai kepercayaan dan evaluasi terhadap atribut-atribut pelayanan dengan cara memberi kriteria atribut dengan skala bipolar, yaitu sangat baik, baik, netral, tidak baik, sangat tidak baik dengan skor 2, 1, 0, -1, -2, kemudian dari pemrosesan informasi tersebut akan membentuk sikap positif dan negative. Dari perkalian antara kepercayaan dan evaluasi akan diketahui sikap seseorang secara keselumhan terhadap atribut-atribut yang dimiliki.

Faktor - Faktor Yang Mempengaruhi Sikap, menurut Bimo Walgito (2001) terdiri dari: 1) Faktor Fisiologis, 2) Faktor pengalaman lagsung terhadap obkjek sikap, 3) Faktor kerangka acuan, 4) Faktor komunikasi seseorang.

Ciri-Ciri sikap. Sikap mempunyai segi-segi perbedaan dengan pendorongpendorong lain yang ada dalam diri manusia itu sendiri. Oleh karena itu untuk membedakan sikap dengan pendorong-pendorong yang lain, terdapat beberapa ciri atau sifat dari sikap tersebut, adapun ciri-ciri sikap itu dalam Bimo Walgito (2001) meliputi: 1) Sikap itu tidak dibawah sejak lahir, 2) Sikap itu selalu berhubungan dengan objek sikap, 3) Sikap itu dapat tertuju pada satu objek saja, tetapi juga dapat tertuju pada sekumpulan objek-objek., 4) Sikap itu dapat bedangsung lama atau sebentar, 5) Sikap itu mengandung factor perasaan dan motifasi

Karakteristik menurut David L.Lauden dan Albert J.Della Bitta (1984), sebagai berikut: 1) Sikap yang memiliki sebuah objek akhirnya harus mempunyai suatu titik pangkal (fokusnya), objek sikap dapat menjadi suatu konsep yang abstrak seperti pemakaian atau hal yang tidak dapat berbentuk suatu bagian dan berbentuk suatu hal yang spesifik atau khusus, 2) Sikap yang memiliki arah, derajat, dan identitas adalah sikap seseorang terhadap suatu objek akan menunjuk suatu arah terhadap objek. Arah sesseorang terhadap objek dapat mendekat dan menjauhi. 3)Sikap yang mempunyai struktur adalah merupakan suatu kerangka organisatoris dari beberapa sikap yang ada pada seseorang yang didalainnya terdapat sejumlah sikap yang tergabung membentuk rangkaian yang kompleks. Masing-masing sikap tersebut mungkin selaras antara satu dengan yang laimiya atau mungkin bertentangan, akan tetapi sikap juga mempunyai kecenderungan untuk mempunyai stabilitas dan mengelompok membentuk struktur sikap yang dapat menjadi umum. 4) Sikap merupakan proses yang dipelajari, artinya sikap dibentuk dari pengalaman-pengalaman individu terhadap realita. Pengalaman tersebut dapat bersifat langsung atau tidak langsung.

Adapun beberapa fungsi-fungsi sikap yang dikemukakan oleh Katz dalam Bimo Walgito (2001) yaitu: 1) Fungsi manfaat adalah berkaitan dengan sarana dan tujuan. Disini sikap merupakan sarana mencapai tujuan. Orang memandang sampaisejauh objek sikap dapat digunakan sebagai sarana atau alat dalam rangka pencapaian tujuan. 2) Fungsi pertahanan ego merupakan sikap yang diambil oleh seseorang demi untuk mempertahankan ego atau akunya. 3) Fungsi ekspresi nilai.Sikap yang ada pada diri seseorang merupakan jalan bagi individu untuk mengekspresikan niklai yang ada dalam 
dirinya. 4) Fungsi pengetahuan.Individu mempunyai dorongan untuk ingin mengerti, dengan pengalaman-pengalamannya, untuk memperoleh pengetahuan.

\section{f. Dimensi Kualitas Pelayanan}

Beberapa pakar pemasaran, seperti Parasuraman, Zeithaml, dan Berry yang dikutip oleh Fandy Tjiptono (2002) berhasil mengidentiftkasi sepuluh faktor utama yang menentukan kualitas jasa. Kesepuluh faktor tersebut meliputi: 1) Rehability, mencakup dua hal pokok, yaitu konsistensi kerja (performance) dan kemampuan untuk dipercaya (dependability). Hal ini berarti perusahaan memberikan jasanya secara tepat semenjak saat pertama (right the first time). Selain itu juga berarti bahwa perusahaan yang bersangkutan memenuhi janjinya, misalnya menyampaikan jasa yang sesuai dengan jadwal yang disepakati. 2) Responsiveness, yaitu kemauan atau kesiapan para karyawan untuk memberikan jasa yang dibutuhkan pelanggan. 3) Competence, artinya setiap orang dalam suatu perusahaan memiliki ketrampilan dan pengetahuan yang dibutuhkan agar dapat memberikan jasa tertentu. 4) Access, meliputi kemudahan untuk dihubungi dan ditemui. Hal ini berarti lokasi fasilitas jasa yang mudah dijangkau, waktu menunggu yang tidak terlalu lama, saluran komunikasi perusahaan mudah dihubungi, dan lain-lain. 5) Courtecy, meliputi sikap sopan santun, respek, perhatian dan keramahan yang dimiliki pada contact (seperti resepsionis, operator telepon, dan lain-lain). 6) Communication, artinya memberikan informasi kepada pelanggan dalam bahasa yang dapat mereka pahami, serta selalu mendengarkan saran dan keluhan pelanggan. 7) Credibility, yaitu sifat jujur dan dapat dipercaya. Kredibilitas mencakup nama perusahaan, reputasi perusahaan, karakteristik pribadi contact personel, dan interaksi dengan pelanggan. 8) Security, yaitu aman dari bahaya, resiko atau keragu-raguan. Aspek ini meliputi keamanan secara fisik (physical safety), keamanan finansial (financial security), dan kerahasiaan (confidentiality). 9) Understanding/knowing the customer, yaitu usaha untuk memahami kebutuhan pelanggan. 10) Tangibles, yaitu bukti fisik dari jasa berupa fasilitas fisik, peralatan yang dipergunakan, representasi fisik dari jasa

Dalam penelitian mereka lebih lanjut, ketiga peneliti ini mengemukakan ada dua tingkat harapan pelanggan pada jasa yaitu adequate service dan desired service. Yang pertama adalah tingkat kinerja jasa minimal yang bisa diterima. Ini didasari oleh perkiraan tentang jasa apa yang mungkin akan diterima dan tergantung pada alternatif yang tersedia. Sedangkan yang kedua adalah tingkat kinerja jasa yang diharapkan pelanggan diterimanya, yang merupakan gabungan dari harapan yang bisa dan harus diterimanya. Daerah diantara kedua tingkat harapan ini disebut dengan zone toleransi (zone of tolerance).

Berdasarkan uraian di atas maka faktor-faktor sikap yang diteliti meliputi: 1) Reliability (ketepatan dalam pelayanan) 2) Responsiveness (kesiapan karyawan melayani konsumen), 3) Competence (ketrampilan dan pengetahuan yang memadai), 4) Access (kemudahaan untuk dihubungi atau ditemui), 5) Courtacy (sikap yang sopan, respek, dan ramah atau kekeluargaan), 6) Communication (memberikan informasi jelas dan mendengarkan saran atau keluhan konsumen), 7) Credibility (sikap jujur dan dapat dipercaya), 8) Security (tempat aman secara fisik, finansial maupun kerahasiaan), 9) Knowing the customer (memahami kebutuhan pelanggan), 10) Tangibles yaitu bukti fisik (makanan khas, lokasi nyaman dan bersih, parkir luas dan mudah, desain kios yang menarik, harga terjangkau) 


\section{METODE PENELITIAN}

Penelitian ini dilaksanakan pada pusat kuliner belut Godean Sleman Yogyakarta. Waktu penelitian direncanakan selama satu tahun. Data yang dikumpulkan dalam penelitian ini berupa data primer. Data primer dikumpulkan sendiri oleh peneliti dengan menggunakan alat kuesioner. Populasi dalam penelitian ini adalah konsumen pusat kuliner belut Godean Sleman Yogyakarta. Sampel diambil sebanyak 100 konsumen dengan menggunakan metode Convenience Sampling. Dalam penelitian ini, data yang diperoleh akan dianalisis dengan menggunakan analisis indeks sikap.

Variabel atau atribut yang digunakan dalam penelitian ini mengacu pada variabel atau atribut yang digunakan oleh Parasuraman et.al. untuk mengevaluasi kualitas jasa atau pelayanan. Adapun atribut yang digunakan dalam penelitian ini meliputi atribut reliability responsivenus, competence, access, comunication, credibility, security, knoring the customer dan cangibles. Analisis Indeks Sikap. Analisis ini menggunakan model multiatribut Fishbein berikut ini:

$$
\mathrm{A}_{\mathrm{o}}=\sum_{i=1}^{n} b_{i} e_{i}
$$

Keterangan:

Ao : Sikap konsumen terhadap pelayanan pusat kuliner belut Godean Sleman Yogyakarta

$\mathrm{b}_{\mathrm{i}} \quad$ : keyakinan konsumen terhadap atribut ke-i

$\mathrm{e}_{\mathrm{i}}$ : evaluasi konsumen terhadap atribut ke-i

$\mathrm{n} \quad$ : jumlah atribut/variable yang digunakan

Pengukuran terhadap variabel atau atribut penelitian tersebut menggunakan teknik skala kutub. Skala ini melibatkan serangkaian pertanyaan yang berkaitan dengan sikap, Responden diminta untuk menyatakan Sangat Baik, Baik, Netral, Tidak Baik, Atau Sangat Tidak Baik.

Tabel 2

Interval Penilaian Sikap

\begin{tabular}{|c|c|c|}
\hline No & Keterangan & Interval Skor \\
\hline 1 & Sangat baik & $31,20 \leq$ Ao $<52,00$ \\
\hline 2 & Baik & $10,4 \leq$ Ao $<31,20$ \\
\hline 3 & Netral & $-10,4 \leq$ Ao $<10,4$ \\
\hline 4 & Tidak Baik & $-31,2 \leq$ Ao $<-10,4$ \\
\hline 5 & Sangat tidak baik & $-52 \leq$ Ao $<-31,2$ \\
\hline
\end{tabular}

Sumber: Hasil perhitungan

Keterangan :

Skor terendah $=-52$; Skor tertinggi $=+52$; kategori 5 Interval $=20,8$ maka diperoleh batasan kategori seperti dalam tabel tersebut. 
Tabel 3

Penilaian Sikap Per Atribut

\begin{tabular}{|c|c|c|}
\hline No & Keterangan & Interval Skor \\
\hline 1 & Sangat tidak baik & $<-2,4$ \\
\hline 2 & Tidak baik & $-2,4 \mathrm{~s} / \mathrm{d}-0,8$ \\
\hline 3 & Netral & $-0,7 \mathrm{~s} / \mathrm{d} 0,7$ \\
\hline 4 & Baik & $0,8 \mathrm{~s} / \mathrm{d} 2,4$ \\
\hline 5 & Sangat baik & $>2,4$ \\
\hline
\end{tabular}

Sumber: Hasil perhitungan

Keterangan :

Skor sikap terendah $=-4$

Skor sikap tertinggi $=4$

$$
\text { Klas Interval }=\frac{4-(-4)}{5}=1,6
$$

\section{PEMBAHASAN}

Perhitungan sikap konsumen terhadap pelayanan Pusat Kuliner Belut Godean Sleman Yogyakarta berdasarkan tingkat keyakinan dan evaluasi atau penilaian konsumen terhadap atribut-atribut yang digunakan dalam penelitian ini, yang mengacu pada atribut yang digunakan oleh Parasuraman et. al, dapat dilihat pada tabel 5.29 di bawah, dengan menggunakan model sikap Martin Fishbein, formulasinya adalah sebagai berikut:

$$
\mathrm{A}_{0}=\sum_{i=1}^{n} b_{1} \cdot e_{i}
$$

Keterangan:

Ao $=$ Sikap konsumen secara keseluruhan

$\mathrm{b}_{\mathrm{i}} \quad=$ Kepercayaan seseorang terhadap atribut (i) yang dimiliki objek

$\mathrm{e}_{\mathrm{i}} \quad=$ Evaluasi seseorang terhadap atribut (i) yang ada pada objek

$\mathrm{n} \quad=$ Jumlah konsumen yang menjadi sampel

adapun nilai keyakinan konsumen (bi) dan evaluasi konsumen (ei) dapat dilihat pada tabel 3 dan tabel 4 di bawah ini:

Berdasarkan hasil perhitungan rata-rata keyakinan (bi) di atas dapat diuraikan nilai keyakinan konsumen (bi) sebagai berikut :

Tabel 3

Keyakinan Konsumen (bi)

\begin{tabular}{|c|c|c|}
\hline Atribut keyakinan & Nilai keyakinan & Artinya \\
\hline Reliability & 0,38 & Netral (biasa saja) \\
Responsiveness & 0,42 & Baik \\
Competence & 0,72 & Baik \\
\hline
\end{tabular}




\begin{tabular}{|c|c|c|}
\hline Access & 1,58 & Sangat baik \\
Courtecy & 0,60 & Baik \\
Communication & 0,64 & Baik \\
Credibility & 1,44 & Sangat baik \\
Security & 0,60 & Baik \\
Understanding & 0,52 & Baik \\
Tangibles (toko) & 0,52 & Baik \\
Tangibles (parkir) & 1,28 & Sangat baik \\
Tangibles (tempat ibadah) & $-0,40$ & Tidak baik \\
Tangibles (toilet) & $-0,96$ & Tidak baik \\
\hline
\end{tabular}

Sumber : Data yang diolah

Perhitungan sikap konsumen terhadap pelayanan Pusat Kuliner Belut Godean Yogyakarta berdasarkan penilaian atau evaluasi terhadap atribut-atribut yang digunakan dalam penelitian ini adalah sebagai berikut:

Tabel 4

Evaluasi konsumen (ei)

\begin{tabular}{|c|c|c|}
\hline Akibat evolusi & Nilai evaluasi & Artinya \\
\hline Reliability & 0,78 & Baik \\
Responsiveness & 0,80 & Baik \\
Competence & 0,82 & Baik \\
Access & 1,28 & Sangat baik \\
Courtecy & 0,78 & Baik \\
Communication & 0,88 & Baik \\
Credibility & 1,04 & Baik \\
Security & 0,64 & Baik \\
Understanding & 0,52 & Baik \\
Pertokoan & 0,52 & Baik \\
Perparkiran & 0,84 & Baik \\
Sarana ibadah & $-0,60$ & Tidak baik \\
Sarana kamar mandi & $-0,72$ & Tidak baik \\
\hline
\end{tabular}

Sumber: data yang diolah

Berdasarkan tabel 3 dan tabel 4 di atas besarnya sikap konsumen dapat diketahui sebagaimana tercermin pada tabel 5 di bawah ini:

Tabel 5

Sikap konsumen terhadap pelayanan Pusat Kuliner Belut Godean Sleman Yogyakarta berdasarkan tingkat keyakinan (bi) dan evaluasi (ei)

\begin{tabular}{|c|c|c|c|c|}
\hline Akibat pelayanan & $\begin{array}{c}\text { Keyakinan } \\
\text { konsumen (bi) }\end{array}$ & $\begin{array}{c}\text { Evaluasi } \\
\text { konsumen } \\
(\mathrm{ei})\end{array}$ & $\begin{array}{c}\text { Sikap } \\
\text { konsumen } \\
\text { (Ao) }\end{array}$ & Artinya \\
\hline Reliability & 0,38 & 0,78 & 0,30 & Netral \\
Responsiveness & 0,42 & 0,80 & 0,34 & Netral \\
Competence & 0,72 & 0,82 & 0,59 & Netral \\
Access & 1,58 & 1,28 & 2,02 & Baik \\
\hline
\end{tabular}




\begin{tabular}{|c|c|c|c|c|}
\hline Courtecy & 0,60 & 0,78 & 0,47 & Netral \\
Communication & 0,64 & 0,88 & 0,56 & Netral \\
Credibility & 1,44 & 1,04 & 1,50 & Baik \\
Security & 0,60 & 0,64 & 0,39 & Netral \\
Understanding & 0,52 & 0,52 & 0,38 & Netral \\
Tangibles (toko) & 0,52 & 0,52 & 0,27 & Netral \\
Tangibles (pakir) & 1,28 & 0,84 & 1,08 & Baik \\
Tangibles (t.ibadah) & $-0,40$ & $-0,60$ & 0,24 & Netral \\
Tangibles (toilet) & $-0,96$ & $-0,72$ & 0,69 & Netral \\
\hline Total & - & - & 8,71 & \\
\hline
\end{tabular}

Sumber : data yang diolah

Berdasarkan tabel 5.29 diperoleh indek sikap konsumen (Ao) terhadap pelayanan Pusat Kuliner Belut Godean Sleman Yogyakarta sebesar 8,71 hal ini berarti konsumen secara keseluruhan atribut pelayanan mempunyai sikap yang biasa saja (netral) pada Pusat Kuliner Belut Godean Sleman Yogyakarta. Dengan demikian atribut-atribut sikap konsumen masih perlu peningkatan atau perbaikan terutama atribut-atribut yang disikapi konsumen netral. Dalam hal ini, yang disikapi netral meliputi reliability, responsiveness, competence, courtecy, comunication, security, understanding, tangibles (toko), tangibles (tempat ibadah), dan tangibles (toilet). Sedangkan yang disikapi sudah baik adalah access, credibility dan tempat parkir sedangkan yang disikapi sangat baik tidak ada.

\section{KESIMPULAN DAN SARAN}

1. Kesimpulan

Berdasarkan hasil dan pembahasan di atas dapatlah diambil beberapa kesimpulan di bawah ini:

a. Konsumen mempunyai sikap yang biasa saja (netral) berdasarkan keyakinan dan evaluasi konsumen pada atribut - atribut pelayanan yang digunakan dalam penelitian ini $($ Ao $=8,71=$ netral $)$.

b. Konsumen mempunyai sikap terbaik pada atribut access Pusat Kuliner Belut Godean Sleman Yogyakarta, sedangkan sikap terburuk pada atribut sarana ibadah.

c. Keyakinan konsumen terbaik pada atribut pelayanan access, sedangkan keyakinan konsumen terburuk pada atribut pelayanan sarana toilet.

d. Evaluasi konsumen terbaik juga pada atribut pelayanan access, sedangkan evaluasi konsumen terburuk pada atribut pelayanan sarana toilet.

2. Saran-saran

a. Atribut pelayanan yang perlu dipertahankan atau bila memungkinkan ditingkatkan lagi adalah atribut access, credibility dan tangibles (tempat parkir).

b. Atribut pelayanan yang perlu mendesak dibenahi adalah atribut tempat ibadah, understanding, sarana toilet, fasilitas kios, security, sarana komunikasi, courtecy, competence, responsiveness, dan reliability. Dengan perbaikan atribut, pelayanan yang disikapi rendah oleh konsumen, diharapkan Pusat Kuliner Belut Godean Sleman Yogyakarta nantinya diprediksikan akan lebih banyak dikunjungi oleh wisatawan atau konsumen. 


\section{DAFTAR PUSTAKA}

Allcock, A. 2006. Pacific 2020 Background Papre: Tourism. Canberra: AusID.

Arieta, S. 2010. Community Based Tourism Pada Masyarakat Pesisir; Dampaknya Terhadap Lingkungan dan Pemberdayaan Ekonomi. Jurnal Dinamika Maritim Vol. 2 No.1, September 2010, hal. 71-79.

Bimo walgito, 2001, Psikologi Industri, Yogyakarta. Andi

Fandi Tjiptono 2001, Manajemen Jasa. Yogyakarta Andi

http://travel.kompas.com/read/2013/05/01/09141484/Asita.Yogyakarta.Bidik.Wisatawan ASEAN, diakses pada tanggal 27 November 2013.

Irianto, 2011. Dampak Pariwisata terhadap Kehidupan Sosial dan Ekonomi Masyarakat di Gili Trawangan Kecamatan Pemenang Kabupaten Lombok Utara. Jurnal Bisnis dan Kewirausahaan Vol. 7 No. 3 Nopember 2011, hal. 188-196.

Jurnal Kajian Lemhanas, 2012. Pengembangan Ekonomi Kreatif Guna Menciptakan Lapangan Kerja dan Mengentaskan Kemiskinan dalam Rangka Ketahanan Nasional. Jurnal Kajian Lemhanas Edisi 14, Desember 2012, hal. 4-11.

Meyer, D. 2006. Carribeian Tourism, Local Sourcing cmd Enterprise Development: Review of the Literature. Diakses dari http://www.odi.org.uk/sites/odi.org.uk/files/odi-assets/publications-opinion files/403 8 .pdf pada tanggal 27 November 2013.

Mitchell J. dan Faal, J. 2007. Holiday Package Tourism and the Poor in the Gambia. Development Southern Africa, Vol. 24, No. 3.

Moh. Liga Suryadana. 2009. Perkembangan Industri Makanan (Kuliner). Disampaikan pada Seminar Sehari CREPS 2009, yang diselenggarakan oleh Program Studi Manajemen Industri Katering, Fakultas Pendidikan dan Ilmu Sosial, Universitas Pendidikan mdonesia Bandung, 14 Oktober 2009. Diakses dari http:/file.upi.edu/Direktori/FPIPS/LAINNYA/LIGA SURYADANA/ Perkembangan industri kuliner.pdf pada tanggal 27 November 2013.

Neto, F. 2003. A New Year Approach to Sustainable Tourism Development: Moving Beyond Environmental Protection. Desa Discussion Papar, No. 29, United Nations.

Pitana, I.G. dan Gayatri, P.G. 2005. Sosiologi Pariwisata. Yogyakarta: CV Andi Offset. 
Pusat Peluang Usaha dan Promosi Bisnis UMKM, 2009. Peluang Usaha Pembuatan Bakpia Skala Rumah Tangga Bisa Merambah ke Skala Industri. Diakses dari http://bisnisukm.com/usaha-pembuatan-bakpia-skala-rumah-tangga-hingga-skalaindustri.html) pada tanggal 27 November 2013.

Sitorus, F. dan I.H. Agusta. 2004. Metodologi Kajian Komunitas. Departemen Ilmu-Ilmu Sosial Ekonomi Fakultas Ilmu Pertanian Institut Pertanian Bogor dan Program Pasca Sarjana Institut Pertanian Bogor, Bogor.

Sorensen, T., dan R. Epps, 2003. The Role of Tourism in the Economic. Transformation of the Central West Queensland Economy. Australian Geographer, Vol. 34, No. 1, pp. 73-89.

Sumardjo dan Saharudin. 2003. Metode-Metode Partisipatif ddlam Pengembangan Masyarakat. Bogor: IPB press.

Suwantoro, G. 2004. Dasar-Dasar Pariwisata. Yogyakarta: ANDI.

Suratmo, G. 2004. Analisis Mengenai Dampak Lingkungan. Yogyakarta: Gadjah Mada University Press.

Tetsu, K. 2006. Tourism Development and Regional Development in Low-•Sf- Income Developing Countries. The Pakistan Development Review 45: 3 / (Autumn 2006) pp. 417-424.

Wahyudi, H. 2012. Pariwisata, Pengetasan Kemiskinan dan MDGs. Diakses dari http://www.pustaka.ut.ac.id/dev25/pdfprosiding2/fisip201219.pdf pada tanggal 27 November 2013.

Yoeti, O. A. 2003. Tours and Travel Marketing. Jakarta: Pradnya Paramita.

Yoeti, O.A. 2008. Ekonomi Pariwisata: Introduksi, Informasi, dan Implementasi. Jakarta: Penerbit Kompas. 